\title{
INTENSYWNA PODRÓZ: OD PSYCHOANALIZY DO SCHIZOANALIZY KINA
}

\author{
AGNIESZKA KOTWASIŃSKA
}

\begin{abstract}
Abstrakt: Celem artykułu jest prześledzenie wpływu krytyki psychoanalitycznej doksy, zaprezentowanej w Anty-Edypie przez Gillles'a Deleuze'a i Feliksa Guattariego, na angloamerykańską teorię filmową ostatnich dwóch dekad. W pierwszej części autorka przybliża specyficzny impas teoretyczny, w który wpadło filmoznawstwo, zbyt mocno skupiając się na psychoanalitycznych ścieżkach interpretacyjnych obracających się wokół identyfikacji, relacji widz-ekran oraz przedstawienia. W drugiej części artykułu autorka prezentuje wybrane publikacje wchodzące w kreatywny dialog zarówno z psychoanalizą kina, jak i schizoanalizą oraz przedstawia przykładowe interpretacje dwóch słynnych horrorów: Psychozy oraz Świtu śymych trupów. W obu przypadkach psychoanalityczny komentarz zostaje odsunięty na bok, a na pierwszy plan wysuwa się deleuzjańsko-guattariańska idea pragnienia oraz afektywne doświadczanie filmu.
\end{abstract}

Słowa kluczowe: Anty-Edyp, schizoanaliza, kino, teoria filmu, psychoanaliza, doznanie, horror, Psychoza, zombie, przedstawienie. 
Trudno mówić o Anty-Edypie w odłączeniu od Tysiaca plateau, chociaż na pierwszy rzut oka wydaje się, że oba tomy Kapitaližmu i schizofrenii Gilles’a Deleuze’a i Féliksa Guattariego więcej dzieli niż łączy. Quasi-schizofreniczne rozszczepienie widać już na poziomie struktury, która w Anty-Edypie wciąż powraca do drzewiastego ukorzenienia i linearnej logiki, a w Tysiacu plateau opiera się na kłączowatej wielości, logice skojarzeń i maszynowych syntezach generowanych przez czytelników i czytelniczki w akcie czytania. Można pokusić się o tezę, że najważniejsze przesunięcie językowe - od schizoanalizy do kłączowatości - którego dokonują Deleuze i Guattari, przechodząc od pierwszego do drugiego tomu swojego magnum opus, unaocznia ruch przejścia od gęsto utkanej i teoretycznie wymagającej krytyki kapitalizmu i psychoanalizy do nieco surrealistycznego połączenia praktycznych narzędzi z quasipoetyckim rozpisaniem się (rozpasaniem?). W Anty-Edypie dwaj autorzy poświęcają bardzo dużo miejsca oczyszczaniu pola myślenia ze stwardniałych naleciałości psychoanalitycznych, natomiast w Tysiacu plateau skupiają się przede wszystkim na tym, jak schizoanalityczna siatka pojęciowa może funkcjonować w praktyce i przekształcać pole społeczne. Ten podział, z pewnością chwiejny, acz nadal użyteczny, pomaga zrozumieć wpływ, jaki Kapitaliżm i schizofrenia wywarł na anglojęzyczne filmoznawstwo ostatnich dwóch dekad, ze szczególnym uwzględnieniem zaprezentowanej w Anty-Edypie krytyki doksy psychoanalitycznej.

$\mathrm{Na}$ wstępie chciałabym zaznaczyć, że zaprezentowana poniżej lista publikacji nie jest z pewnością wyczerpująca. Stanowi ona raczej siłą rzeczy skrócony zapis mojej własnej „intensywnej podróży” prowadzącej od psychoanalitycznych eksploracji anglojęzycznego horroru w publikacjach $\mathrm{z}$ lat siedemdziesiatych i osiemdziesiatych, przez feministyczne reewaluacje freudowskich i lacanowskich narzędzi w latach dziewięćdziesiątych, po współczesne publikacje badające tzw. gatunki niskie i zaakcentowane w nich silnie kwestie ucieleśnienia i upłciowionych przedstawień. Moje własne zmęczenie psychoanalitycznym aparatem teoretycznym odbija się szerokim echem w książkach, których autorzy i autorki, tak jak ja, szukają wytchnienia od czarnej dziury filmowego pragnienia-braku, sa znużeni dystansem wobec materialności doświadczenia filmowego i szukają wyjścia z politycznego impasu, za sprawą którego transgresyjne obrazy są zbyt łatwo romantyzowane, a kino głównego nurtu (i kino gatunkowe) jest albo skreślane jako reakcyjne i ogłupiające, albo „przechwytywane” przez aparat kulturoznawczy.

Nim jednak przejdę do konkretnych przykładów, warto zapytać, w jakim celu filmoznawcy i filmoznawczynie zaglądaja do Anty-Edypa czy Tysiaca plateau, skoro Gilles Deleuze poświęcił kinu aż dwie książki (wydane po polsku w jednym tomie): Kino. 1. Obrazruch, 2. Obraz-czas (2008). Wydawać by się mogło, że te dwa dzieła powinny w zupełności wystarczać jako kanwa deleuzjańskiej teorii kina. Tym bardziej, że Deleuze wprowadza w nich zupełnie świeży język teoretyczny dla mówienia o kinie i nowy aparat pojęciowy, skupiający się wokół Bergsonowskich „koncepcji trwania, ruchu czy postrzegania” (Ples 2011, 375) 
i sięgający chętniej do teorii znaków Charlesa S. Pierce’a niż do strukturalistycznej semiotyki. Ale, jak przyznaje filmoznawczyni i filozofka Patricia MacCormack, Deleuze'a w jego książkach o kinie bardziej zajmuje zawartość filmów niż procesy patrzenia, doświadczania czy identyfikacji, które z kolei stanowią trzon feministycznej (i psychoanalitycznej) teorii filmowej $(2016,8)^{1}$. I choć wiele teoretyczek i teoretyków rzeczywiście opiera się wyłącznie na tych dwóch pozycjach (np. Colman 2011, Rodowick 1997), a w antologiach tekstów poświęconych Deleuze'owi i kinu (np. Flaxman 2000, Buchanan i MacCormack 2008) szala wciąż przechyla się na stronę Obrazu-ruchu i Obrazu-czasu, to widać coraz wyraźniejszy wzrost zainteresowania deleuzjańsko-guattariańskią siatką pojęciowa, szczególnie wśród badaczy i badaczek poruszających się wzdłuż punktów przecięcia krytyki feministycznej, filozofii i filmoznawstwa. Tutaj właśnie na plan pierwszy wysuwa się prawdopodobnie najbardziej użyteczny dla filmoznawstwa element $A n t y-E d y p a$, jakim jest wielopoziomowa dekonstrukcja i krytyka psychoanalizy oraz freudowsko-lacanowskiej seksualności. Zarówno sama krytyka psychoanalizy, jak i zaproponowana przez Deleuze'a i Guattariego schizoanaliza pozwalaja badaczkom i badaczom kina zakwestionować (lub chociaż odsunąc na bok) nadrzędność identyfikacji i przedstawienia, filmowe pragnienie rozumiane poprzez brak, relacje widz-film opartą wyłącznie na ekonomii wizualnej czy wreszcie dyskursywne ujęcie ciała i cielesności.

Sami autorzy Anty-Edypa opisują schizoanalizę jako

analizę transcedentalną i materialistyczna. Jest [ona] zatem krytyką w tym sensie, w jakim prowadzi do krytyki Edypa lub doprowadza Edypa do własnej samokrytyki. Za przedmiot swoich badań obiera nieświadomość transcendentalną zamiast nieświadomości metafizycznej; analizuje jej charakter materialny zamiast skupiać się na jej wymiarze ideologicznym; koncentruje się na nieświadomości schizofrenicznej zamiast edypalnej; niefiguratywnej zamiast wyobrażeniowej; realnej zamiast symbolicznej; maszynowej zamiast strukturalnej; molekularnej, mikropsychicznej i mikrologicznej zamiast molowej i stadnej; interesuje ją wytwórcza natura nieświadomości, nie zaś jej ekspresywny charakter (Deleuze i Guattari 2017, 129).

Odejście od ideologii, wyobrażenia, symboliki, wreszcie struktur molowych, opisujących sztywną segmentację i zamknięcie w hierarchicznych strukturach społecznych i tożsamościowych, uwalnia teorię kina od nieświadomości odtwórczej, przewidywalnej, teatralnej, „która jedyne, co potrafi, to wyrażać siebie (w micie, tragedii, marzeniu sennym)” (Deleuze i Guattari 2017, 29).

\footnotetext{
${ }^{1}$ Zobacz również krytykę deleuzjańskiej teorii kina pióra Richarda Rushtona opublikowaną w Screen w 2009.
} 
Tym samym krytyka psychoanalizy pozwala na potencjalne wyjście z impasu, w którym utkwiło anglojęzyczne filmoznawstwo końca dwudziestego wieku. Anna Powell (2007) zwraca uwagę na podwójny ruch w obrębie brytyjskiego filmoznawstwa: po początkowym zachłyśnięciu się tzw. teorią Screen (krytyką skupioną wokół czasopisma Screen i czerpiącą głównie z teorii francuskiej, althusseriańskiego marksizmu i lacanowskiej psychoanalizy), brytyjska teoria filmowa przesunęła punkt ciężkości na badania kulturoznawcze (Powell 2007, 6-7). Innymi słowy, w momencie gdy psychoanalityczna teoria kina wytraciła impet, a jej popularność nieco osłabła, filmoznawcy i filmoznawczynie zaczęli poszerzać warsztat metodologiczny, podążając w kierunku socjologicznej i historycznej analizy produkcji filmowej i przedstawień, kognitywizmu, teorii odbioru oraz, ogólnie, większej intersekcjonalności, interdyscyplinarności i otwartości na formy popularne. Warto jednak podkreślić, że psychoanalityczne teorie filmowe nie zostały wykluczone z krytycznego obiegu; wręcz przeciwnie, wraz z intersekcjonalnymi, kulturoznawczymi perspektywami stanowią one dziś trzon współczesnej krytyki filmowej.

Nie zmienia to jednak faktu, że dla wielu badaczy i badaczek anglojęzyczne filmoznawstwo utknęło w martwym punkcie. Impas ten szczegółowo opisuje Teresa Rizzo (2012), zwracając uwagę na znaczne zmniejszenie obecności na akademickich kursach w pierwszych latach dwudziestego pierwszego wieku feministycznej teorii kina - teorii, która zdobyła szturmem akademickie salony w ostatnim ćwierćwieczu XX wieku i która skupia się przede wszystkim na zagadnieniach różnicy płciowej, reprezentacji kobiet i teorii widza (spectatorship theory) (Rizzo 2012, 5-7). Powstała luka nie została wypełniona nowa teoria, co Rizzo (za Mary Ann Doane) tłumaczy zmęczeniem konceptem dyspozytywu kina (cinematic apparatus), kojarzonym przede wszystkim z pismami Jean-Louisa Baudry'ego (1975) oraz Christiana Metza (1982) - konceptem który zakłada ideologiczny wymiar każdego aspektu filmu, od scenariusza przez montaż, efekty dźwiękowe, ruch kamery aż po relację widz-ekran rozumiana zawsze przez pryzmat identyfikacji. Głównym zarzutem wobec dyspozytywu kina, jak zwraca uwagę Rizzo, jest właśnie formalistyczne powiązanie aktu patrzenia z identyfikacja, która z kolei opiera się tu na popularnych teoriach upodmiotowienia, takich jak np. voyeuryzm i formowanie ego u Freuda, lacanowski podmiot i faza lustra, althusserowska interpelacja czy wreszcie jednoobiektywowa (monocular) perspektywa odziedziczona po malarzach renesansu (Rizzo 2012, 18). Ta ostatnia kategoria wiąże się bezpośrednio $z$ ideą transcedentalnego podmiotu, wszystkowidzącego i wszechwiedzącego, ahistorycznego i bezcielesnego, co w praktyce dość gładko przekłada się na białego, pełnosprawnego mężczyznę z klasy średniej. Jak dodaje Steven Shaviro (1993), to, co odrzuca go od założycielskich tekstów psychoanalitycznej i, szerzej, (post)strukturalistycznej teorii kina, to obecny w nich ,prawie bezwarunkowy odruch podejrzenia, wyparcia i fobicznego odrzucenia" (Shaviro 1993, 10). Według Shaviro, wyparcie własnej ucieleśnionej pozycji 
jako widza (i krytyka), ukrycie jej pod płaszczykiem wspinania się na wyżyny wysokiej teorii maskuje „panikę na myśl o tym, że formy wizualne moga (a może już to zrobiły?) poruszyć i wpłynąć na teoretyczkę" poniekąd bez jej wiedzy i zgody (Shaviro 1993, 13-14).

Warto podkreślić, że feministyczna krytyka dyspozytywu kinowego, formułowana najczęściej z pozycji psychoanalitycznych (np. Mulvey 1975, Doane 1987, Modleski 1988, Silverman 1988, Copjec 1994), otworzyła filmoznawstwo na zupełnie nowe modele interpretacyjne, często w nowatorski sposób podejmujące kwestie różnicy płciowej, relacji widz-film i ucieleśnienia (np. Williams 1989, Clover 1993). Mimo to, jak skarży się Shaviro, żaden $\mathrm{z}$ tych tekstów nie był w stanie wyjść poza semiotyczny/psychoanalityczny model ustanowiony przez Metza (Shaviro 1993, 12) i odtwarzany przez kolejnych krytyków i krytyczki. Co ciekawe, gatunki niskie (pornografia, horror) czy też wysokobudżetowe kino głównego nurtu (komedie, musicale, filmy SF) okazały się wdzięcznym materiałem analitycznym ze względu na ich bezpardonowe podkreślanie udziału ciała widza w doświadczeniu filmowym, co w kinie niezależnym i artystycznym ma miejsce zdecydowanie rzadziej. Sam Shaviro jest zresztą jednym z pierwszych teoretyków deleuzjańskoguattariańskiego filmoznawstwa, którzy kontynuuja badania w ramach tego zwrotu ku ,gatunkom cielesnym” (Williams 1991). Nic więc dziwnego, że badaczki i badacze chcący wejść w produktywny dialog z psychoanalityczną teorią kina decydują się często na podobny materiał źródłowy, co widać chociażby w publikacjach Anny Powell (2005, 2007), Barbary M. Kennedy (2000), Patricii Pisters (2003, 2012), Martine Beugnet (2007) czy Eleny del Rio (2008).

W The Cinematic Body Shaviro poświęca dwa rozdziały oryginalnej trylogii zombie George'a Romero oraz horrorowi cielesnemu (body horror) Davida Cronenberga. Warto zatrzymać się na moment przy jego analizie Świtu sywych trupów (1978) i przyjrzeć się z bliska fermentowi, który wprowadzają w tym miejscu Deleuze i Guattari z ich rekonceptualizacja pragnienia i podważeniem prymatu przedstawień. Marksistowsko-psychoanalityczna analiza filmu o grupie przypadkowych osób zabarykadowanych w centrum handlowym podczas zombie-apokalipsy prowadzi do przewidywalnych wniosków: reżyser potępia rozbuchany konsumpcjonizm amerykańskiego społeczeństwa, odkrywa społeczną anomię i atawistyczne bestialstwo ledwie skryte pod cienką warstewką nominalnego uspołecznienia oraz krytykuje łatwość, z jaką ludzie poddaja się transformacji w „żywe trupy” kapitalizmu: istoty bezmyślne, bezduszne, wiecznie wybrakowane. Shaviro nie tyle odrzuca wyżej wymienione tezy, co raczej zmienia ustawienie maszyny analitycznej. Pragnienie, jedno z kluczowych pojęć sformułowanych w Anty-Edypie, nie opiera się już na lacanowskim braku, na pustce pozostawionej po wiecznie odwlekanym Realnym, ale jest siłą generatywną samą w sobie, feerią impulsów, intensywności, przepływów. Stąd też Shaviro postuluje, że „pojawienie się żywych trupów w centrum handlowym nie może być już interpretowane jako powrót 
wypartego. Zombie nie sa wyjątkiem wobec konsumpcyjnego pragnienia, ale jego pozytywnym wyrazem. Wyłaniaja się nie z mrocznych, wzgardzonych piwnic podmiejskiego życia, ale z jego tandetnej połyskliwej powierzchni" (Shaviro 1993, 92). Zombie nie są obrazem zwichniętego pragnienia, ale raczej mimetycznym ucieleśnieniem „kapitalistycznej logiki niekończącej się konsumpcji i wiecznie powiększającego się gromadzenia dóbr” (Shaviro 1993, 93). Jak dodaje autor, „[p]otrzeba jest funkcją nadmiaru i ekstrawagancji, a nie deficytu: im więcej konsumuję, tym więcej żądam do konsumpcji”" (Shaviro 1993, 92). Jeśli uznamy, że zombie są maszynami pragnącymi, to warto pamiętać, że według Deleuze’a i Guattariego „niczego [one] nie przedstawiają, niczego nie oznaczaja, nie maja żadnego znaczenia, są bowiem dokładnie tym, z czego są zrobione, sa tym, co się z nich tworzy, tym, co tworzą z samych siebie" (Deleuze i Guattari 2017, 336).

Zombie problematyzują tym samym kwestię przedstawienia, gdy przechwytują potencjalną identyfikację widzów z głównymi postaciami (nie-zombie) w ramach „procesu empatycznego uczestnictwa” (Shaviro 1993, 52). Oglądając Świt żymych trupów, widz „zostaje unieruchomiony i przemieniony w następstwie wejścia w zaraźliwy, głęboko fizyczny kontakt z obrazami” (Shaviro 1993, 52). Zarażenie zakłada fizyczny kontakt, utratę kontroli, mutację, co stoi w całkowitej kontrze do przedstawienia, zapewniającego bezpieczny dystans, ochronę i klarowny podział na obserwującego i obserwowanego (którego nie znosi nawet kontridentyfikacja ${ }^{2}$. Deleuze i Guattari sprawiaja sprawę jasno: produkcja pragnienia została spłaszczona przez psychoanalizę i obrócona właśnie w przedstawienie (Deleuze i Guattari 2017, 345). Nic więc dziwnego, że autorzy Anty-Edypa sarkastycznie odnoszą się do teatru przedstawienia: „Obrazy, nic poza obrazami. Na koniec pozostaje intymny i rodzinny teatr. [...] Nieświadomość jako scena” (Deleuze i Guattari 2017, 355). Zadaniem schizoanalizy musi być zatem „[o]balić teatr przedstawienia, aby odzyskać porządek produkcji pragnienia” (Deleuze i Guattari 2017, 318).

Wejście w infekcyjną relację z filmem, które proponuje Shaviro, jest według niego szczególnie proste w horrorze i pornografii, które „wyolbrzymiają i uwidaczniają to, co miało pozostać zaledwie drugorzędnym, odroczonym, dodatkowym zaspokojeniem fantazji”" (Shaviro 1993, 100). Oba gatunki są zresztą często deprecjonowane właśnie ze względu na afektywne przeciążenie (wynikające ze strachu, obrzydzenia czy podniecenia), od którego krytycy i krytyczki w psychopatologicznym modelu gładko przechodzą do oskarżeń o mizoginię i reakcyjność ${ }^{3}$. Kategorie masochizmu, abiektu czy kontridentyfikacji

\footnotetext{
2 Więcej o możliwościach i ograniczeniach kontridentyfikacjach w horrorze: Clover 1993 oraz Halberstam 1995.

3 Do tej kategorii można zaliczyć również melodramat, którego materialno-dyskursywnym znakiem byłoby silne poruszenie i łzy. Zob. również: Williams 1991.
} 
nie wystarczają, aby zrozumieć przyjemność odczuwaną przez wielu widzów podczas oglądania horroru ciała Davida Cronenberga lub giallo Dario Argento ${ }^{4}$

Prawie dekadę po książce Shaviro Barbara M. Kennedy zadaje podobne pytanie: jak idlaczego widzowie czerpią przyjemność z filmów politycznie i afektywnie problematycznych, niewłaściwych, niefeministycznych? Podobnie jak Shaviro, Kennedy dostrzega w kinie głównego nurtu, ale i w gatunkach niskich, potencjalne linie ujścia zaburzające fallogocentryczność narracji na rzecz „przypadkowości i wielości doznań” (Shaviro 1993, 63). Jak wyjaśnia autorka Deleuze and Cinema: The Aesthetics of Sensation (2000), w swojej książce nie traktuje ona filmu jako czysto reprezentacyjnego medium, uzależnionego od ekonomii patrzenia i paradygmatu identyfikacji, ale jako układ (assemblage), jako „scalenie umysłu/ciała/maszyny, jako doświadczenie, jako doznanie” (Kennedy 2000, 5). Film w jej ujęciu jest zatem „procesem pragnienia, maszynowym układ pragnienia, w którym podmiotowość zostaje wchłonięta przez znacznie głębszy koncept doznania” (Kennedy 2000, 61-62).

Drugim przykładem zastosowania schizoanalizy jest książka Anny Powell Deleuze and Horror Film (2005), której cała pierwsza połowa poświęcona jest deleuzjańsko-guattariańskim pojęciom stawania-się, schizofrenizacji pragnienia, stanów intensywnych, szaleństwa i Ciała bez Organów. Znamienne, że Powell rozpoczyna swoją intensywną podróż „od psychoanalizy do schizoanalizy” od Psychozy (1960), filmu, z którego psychoanalityczne uproszczenia i stereotypy wylewają się na głowę widza nawet bez pomocy Slavoja Žižka. Płytka (i nieprawidłowa) definicja rozdwojenia jaźni zaserwowana przez filmowego psychiatrę w końcowej scenie sprawnie podsumowuje wachlarz patologii Normana: zbyt bliska relacja z matka, skrajny kompleks Edypa, sadystyczny voyeuryzm, maniakalny transwestytyzm (czy raczej jego sfałszowana i spatologizowana wizja). Wszystkie te szokujące wątki kieruja uwagę odbiorców i odbiorczyń na znajomy rodzinny dramat, małe piekiełko edypalne, w które widzowie zostają uwikłani poprzez płynnie zmieniająca się identyfikację z kobietą (ofiara, ale i przestępczynia) i potworem (godna pożałowania ofiarą Edypa?)5 5

Jak celnie zauważa Powell, strukturalistyczna psychoanaliza kina nie ma dużo do powiedzenia na temat filmu jako „estetycznego i dogłębnie fizycznego doświadczenia” (Powell 2005, 24), a horror kinowy potrafi tłumaczyć jedynie w kategoriach patologicznych (zarówno deskryptywnych, jak i normatywnych). I to dopiero schizoanaliza pozwala dostrzec, na przykład, w jaki sposób schizoidalne linie ujścia penetrują estetykę Psychozy (Powell 2005, 25) już od pierwszych sekund filmu. Agresywne linie przecinające czarny ekran idą w parze z przenikliwą muzyką smyczkową przywodząca na myśl skowyt (ta początkowa przemoc

4 Zobacz również: Creed 1993, Modleski 1988, Clover 1993.

5 Więcej na temat bliskości obu postaci oraz identyfikacji między kobietą a potworem, zob. Williams 1984. 
wizualnych cięć i piskliwych dźwięków skrzypiec zostanie powtórzona w drugiej połowie filmu w słynnej scenie pod prysznicem). Po chwili szare linie i skowyczące skrzypce ustępują miejsca skąpanej w słońcu panoramie miasta, ale prostopadłe i równoległe linie nigdy tak naprawdę nie znikają z ekranu, zamieniają się jedynie w zewnętrzną framugę okna i żaluzje pokoju, w którym główna bohaterka, Marion, właśnie kończy miłosną schadzkę. Powell zwraca uwage, że zmiana tonu $\mathrm{w}$ tej scenie, $\mathrm{z}$ agresywnego na zmysłowy, nie jest w stanie ukoić widza, który został już na samym początku wytrącony z równowagi i, krótko mówiąc, porządnie przestraszony.

Inną ciekawą kwestią poruszoną w tym rozdziale jest wszechobecność ptaków w Bates Motel. Powell nie podchodzi jednak do wypchanych ptaków i ornitologicznych ilustracji pod kątem ich potencjalnej symboliki, ale widzi w nich część układu, element stawania-się-ptakiem Normana. Choć wydaje się, że to raczej stawanie-się-matką Normana powinno być na pierwszym planie, Powell trafnie zauważa, że stawanie-się-ptakiem jest dla bohatera łatwiejsze i, co ciekawe, ten właśnie układ wymyka się freudowskiej strukturze edypalnej (Powell 2005, 26). Ostatecznie jednak Norman staje się matką (w dość smutnym, bo prawie dosłownym znaczeniu), a jego wcześniejsze próby kontrolowania matki i uczynienia z niej de facto kolejnego wypchanego ptaka w jego kolekcji zostaja przekreślone, gdy sam staje się wypchanym człowiekiem w ostatniej scenie.

Psychoza niejako oscyluje między dwoma biegunami szaleństwa, o których pisza Deleuze i Guattari, między „biegun[em] faszyzująco-paranoicznym, który inwestuje w centralna formacje suwerenna, przeinwestowując ja, czyniąc z niej odwieczną i ostateczną zasadę każdej innej historycznej formy społecznej” a „biegun[em] schizo-rewolucyjny[m], który podąża wzdłuż linii ujścia pragnienia, przekracza mur, wywołuje przepływy, składa swoje maszyny" (podkreślenie autorów, Deleuze i Guattari 2017, 323). Oczywiście analiza filmu może dotyczyć tylko inwestycji segregacyjnej, „paranoicznego przeciw-ujścia”, w ramach którego Norman podporządkowuje wszystkie swoje pragnienia figurze matki i pozostaje zamknięty w edypalnym dramacie rodzinnym (Deleuze i Guattari 2017, 396). Równie ciekawy jest drugi typ inwestycji libidynalnej - inwestycja nomadyczna oraz „schizofreniczne ujście, które może przekształcić się w inwestycję rewolucyjną” (Deleuze i Guattari 2017, 396) i które uwalnia pragnienia Normana, prowadząc chociażby ku ptakom. Nic nie stoi na przeszkodzie, aby „stany oscylacji nieświadomości” współistniały i były analizowane równolegle przez teorię kina.

Powell podkreśla, że nie interesuje jej utworzenie „,nowej schizoanalitycznej ortodoksji horroru" i, jak sama przyznaje, jej własne doświadczenie wielokrotnego oglądania Psychozy oscyluje między molowymi a molekularnymi reakcjami i odczytaniami (Powell 2005, 26). Podobnie Rizzo i Kennedy zaznaczają, że głównym celem schizoanalizy kina jest popchnięcie nieco nużących debat wokół dyskursu, performatywności i przedstawienia 
w nowe miejsca poprzez zmianę zarówno aparatu badawczego, jak aparatu myślowego. To zwłaszcza publikacje z ostatnich piętnastu lat najlepiej pokazuja gotowość badaczy i badaczek do podjęcia wyzwania zarysowanego przez Deleuze'a i Guattariego w pracy Co to jest filozofia?, w której podkreślają wartość płynąca ze spotkań sztuki, filozofii i nauki, trzech bliskich sobie domen myślenia. I tak Patricia Pisters wprowadza pojęcie „neuro-obrazu”, aby przybliżyć sposób, w jaki filmy funkcjonują nie jako przykłady, ale jako „,faktyczne ziarna myśli: ważne spotkania, które generują nowe połączenia mózgowe (nowe postrzeganie, nowe uczucia, nowe myśli) i które łączą się lub rezonuja z refleksją filozoficzną i odkryciami naukowymi”'(Pisters 2012, 18). Barbara Kennedy również zauważa produktywne zetknięcia humanistyki i nauk ścisłych, nazywając swój projekt bioestetyką i neoestetyką, i zwracając uwagę na niepodzielność reagowania umysłu/ciała/mózgu.

Neoestetyczna perspektywa, którą proponuje Kennedy, opiera się również w dużej mierze na feministycznych badaniach ucieleśnienia w ramach nowego materializmu nowatorskich interwencjach krytycznych, które podważają nie tylko kartezjański dualizm, ale przede wszystkim antropocentryczność i rzekomą uniwersalność zachodniego podmiotu oraz psychoanalityczne ujęcie różnicy płciowej ${ }^{6}$. Do podobnej kartografii odwołują się również Rizzo oraz Powell. Feministyczny nowy materializm w swoich wielu odsłonach, mutacjach i przeobrażeniach wchodzi w intensywne i produktywne układy m.in. $z$ teoria afektów, filozofią kontynentalną, semiotyką, biologia, neurologia czy fizyką kwantowa, co z kolei otwiera filmoznawcom i filmoznawczyniom drzwi do coraz to śmielszych, niebanalnych i wymagających interpretacji filmów. Ważnym elementem takich prac jest przeniesienie punktu ciężkości z reprezentacji na „afektywne zanieczyszczenie” odbiorczyni (affective contamination) (Guattari 1995, 92), co z kolei dobrze wpasowuje się w postulat zwiększonej wrażliwości i otwartości na politykę umiejscowienia, wiedze usytuowane, osadzenie i ucieleśnienie badaczki w danym czasie i przestrzeni. Nie można jednak zapomnieć, że to właśnie deleuzjańsko-guattariańska krytyka psychoanalizy dała ten pierwszy impuls do zakwestionowania teorii Screen, dyspozytywu kina i płynących z nich wniosków.

Jak jednak przestrzega sama Pisters w Delirium cinema or machines of the invisible? (2008), schizoanalizy nie należy traktować jako uniwersalnego narzędzia. Zachodnie zafiksowanie na podmiotowości i jednostce widoczne w psychoanalizie niekoniecznie przekłada się na inne kultury, szczególnie te, w których to nie rodzina nuklearna, a wspólnota jest jednostką nadrzędna, i to raczej przejście z wielości na wąsko rozumiana podmiotowość stanowi potencjalnie rewolucyjny $\operatorname{ruch}^{7}$. Pisters zauważa również, że traktowanie psychoanalizy

6 Zobacz np. Braidotti 2002, 2009; Grosz 1994, 2008; Coole i Frost (red.) 2010; Alaimo i Hekman (red.) 2009; Barrett i Bolt (red.) 2013.

7 Pisters analizuje film dokumentalny Maleka Bensmaila Alienations (2003), w którym reżyser rozmawia z lekarzami i pacjentami szpitala psychiatrycznego w Algierii. 
i schizoanalizy jako prostego epistemologicznego dualizmu niesie z sobą ryzyko odtwarzania logiki binarnej. Wydaje się, że najlepszą ochroną przed stworzeniem nowego dogmatu schizoanalitycznego jest eksperymentowanie ze schizoanalizą, naginanie jej, przyłączanie do niej nieoczywistych teorii, przeplatanie jej z badaniami z zupełnie odmiennych dziedzin jak np. neurobiologia w przypadku prac Pisters.

Ta ogromna różnorodność teoretyczna sprawia, że trudno mówić o kanonie schizoanalizy kina, tym bardziej, że każda z wyżej wspomnianych książek jest w jakiejś mierze przełomowa właśnie ze względu na swoje interdyscyplinarne podejście i nietypowe zestawienia. Uważne czytelniczki i czytelników może jednak zmartwić pewna powtarzająca się niekonsekwencja obecna w wielu wyżej wymienionych analizach. Chociaż autorki i autorzy odwołują się w ogromnej mierze do Kapitalizmu i schižfrenii, często samo nazwisko Deleuze’a widnieje w tytułach ich książek i rozdziałów, a Guattari albo przemyka we fragmentach dotyczących jego praktyki w klinice La Borde, albo zostaje czasem (nie zawsze!) wymieniony jako współautor koncepcji przedstawionych w Anty-Edypie i Tysiacu plateau. Być może jest to z mojej strony małostkowe, ale fakt pozostaje faktem: poprzez mniej lub bardziej świadome zaniechanie takie koncepcje jak stawanie-się, Ciało bez Organów, kłącze czy też właśnie schizoanaliza zostaja powiązane z samym tylko Deleuze'em, co uważam za wielce niesprawiedliwe wobec Guattariego.

$\mathrm{Na}$ sam koniec wrócę do Powell, która uważa, że to dzięki deleuzjańskiej (a właściwie deleuzjańsko-guattariańskiej) filozofii kina teoria filmowa wreszcie przestaje być „perwersyjna wiwisekcją i zaczyna przypominać metodę spekulatywnego myślenia idąca w parze z potężnym impulsem kreatywnym” (Powell 2007, 3). Pierwszym krokiem do wyjścia z prosektorium, z bloku operacyjnego (operating theatre) jest jednak zrozumienie, że „Edyp jest entropia maszyny pragnącej, jej tendencją do zewnętrznego wygaśnięcia. Jest obrazem lub przedstawieniem [...], kliszą, która zatrzymuje połączenia, wyczerpuje przepływy, umieszcza śmierć w pragnieniu [...], jest Wyłącznikiem” (Deleuze i Guattari 2017, 452). Schizoanaliza ma być zatem Włącznikiem innego zaangażowania w doświadczenie filmowe, innej relacji widz-film i wreszcie innej krytyki. 


\section{Wykaz literatury}

Alaimo, Stacy i Susan Hekman (red.). 2009. Material Feminisms. Bloomington: Indiana University Press.

Barrett, Estelle i Barbara Bolt (red.). 2013. Carnal Knowledge: Toward A »New Materialism« through the Arts. London: I.B. Tauris.

Baudry, Jean-Louis. 1974-1975. „Ideological Effects of the Basic Cinematographic Apparatus." Tłum. Alan Williams. Film Quarterly 28/2: 39-47 [c.1970].

Beugnet, Martine. 2007. Cinema and Sensation: French Film and the Art of Transgression. Edinburgh: Edinburgh University Press.

Braidotti, Rosi. 1994. Metamorphoses Towards a Materialist Theory of Becoming. Cambridge: Polity.

Braidotti, Rosi. 2009. Podmioty nomadyczne. Ucieleśnienie i różnica seksualna w feminizmie współczesnym. Tłum. Aleksandra Derra. Warszawa: Wydawnictwa Akademickie i Profesjonalne.

Buchanan, Ian i Patricia MacCormack (red.). 2008. Deleuze and the Schiroanalysis of Cinema. London: Continuum.

Clover, Carol J. 1993. Men, Women, and Chain Saws: Gender in the Modern Horror Film. Princeton University Press.

Coleman, Felicity. 2011. Deleuze and Cinema: The Film Concepts. Oxford: Berg.

Coole, Diana i Samantha Frost (red.). 2010. New Materialisms: Ontology, Agency, and Politics. Durham: Duke University Press.

Copjec, Joan. 1994. Read My Desire: Lacan Against the Historicists. Cambridge: MIT Press.

Creed, Barbara. 1993. The Monstrous-Feminine: Film, Feminism, Psychoanalysis. London: Routledge.

Deleuze, Gilles. 2008. Kino.1: Obraz-ruch .2: Obrą-czas. Tłum. Janusz Margański. Gdańsk: Wydawnictwo słowo/obraz/terytoria.

Deleuze, Gilles i Félix Guattari. 2017. Anty-Edyp: Kapitalizm i schizofrenia. Tłum. Tomasz Kaszubski. Warszawa: Wydawnictwo Krytyki Politycznej.

Deleuze, Gilles i Félix Guattari. 2000. Co to jest filozofia? Tłum. Paweł Pieniążek. Gdańsk: Słowo/obraz/terytoria.

Deleuze, Gilles i Félix Guattari. 2015. Tysiac plateau: Kapitaližm i schizofrenia II. Red. meryt. Joanna Bednarek. Warszawa: Fundacja Nowej Kultury Bęc Zmiana.

Doane, Mary Ann. 1987. The Desire to Desire: The Woman's Film of the 1940s. Bloomington: Indiana University Press.

Flaxman, Gregory (red.). 2000. The Brain is the Screen: Deleuze and the Philosophy of Cinema. Minneapolis, University of Minnesota Press.

Grosz, Elizabeth. 2008. Chaos, Territory, Art: Deleuze and the Framing of the Earth. New York: Columbia University Press.

Grosz, Elizabeth. 1994. Volatile Bodies: Toward a Corporeal Feminism. Bloomington: Indiana University Press.

Guattari, Félix. 1995. Chaosmosis. An Ethico-Aesthetic Paradigm. Tłum. P. Bains, J. Pefanis. Bloomington, Indianapolis: Indiana University Press.

Halberstam, Judith (Jack). 1995. Skin Shows: Gothic Horror and the Technology of Monsters. Durham: Duke University Press.

Kennedy, Barbara M. 2000. Deleuze and Cinema: The Aesthetics of Sensation. Edinburgh: Edinburgh University Press.

MacCormack, Patricia. 2016. Cinesexuality. Londyn: Routledge. 
Metz, Christian. 1982. The Imaginary Signifier: Psychoanalysis and Cinema. Tłum. Celia Britton et al. Bloomington: Indiana University Press.

Modleski, Tania. 1988. The Women who Knew Too Much: Hitchcock and Feminist Theory. New York: Methuen.

Mulvey, Laura. 1975. „Visual Pleasure and Narrative Cinema”. Screen 16/3: 6-18.

Pisters, Patricia. 2008. „Delirium Cinema or Machines of the Invisible?” W Deleuze and the

Schizoanalysis of Cinema. Red. Ian Buchanan i Patricia MacCormack. London: Continuum.

Pisters, Patricia. 2003. The Matrix of Visual Culture: Working with Deleuze in Film Theory. Stanford: Stanford University Press.

Pisters, Patricia. 2012. The Neuro-Image: A Deleuzian Film-Philosopby of Digital Screen Culture. Stanford: Stanford University Press.

Ples, Marta. 2011. „Obraz, czas, ruch. Kino według Gilles’a Deleuze’a”. Recenzja książki Giles’a Deleuze'a Kino. 1: Obraz-ruch. 2: Obraz-czas. Folia Philosophica 29: 373-376.

Powell, Anna. 2005. Deleuze and Horror Film. Edinburgh: Edinburgh University Press.

Powell, Anna. 2007. Deleure, Altered States and Film. Edinburgh: Edinburgh University Press, 2007.

Rizzo, Teresa. 2012. Deleuze and Film: A Feminist Introduction. London: Continuum.

del Rio, Elena. 2008. Deleuze and the Cinemas of Performance. Edinburgh: Edinburgh University Press.

Rodowick, David. 1997. Gilles Deleuze's Time Machine. Durham: Duke University Press.

Rushton, Richard. 2009. „Deleuzian spectatorship”. Screen 50/1: 45-53.

Shaviro, Steven. 1993. The Cinematic Body. Minneapolis: University of Minnesota Press.

Silverman, Kaja. 1988. The Acoustic Mirror: The Female Voice in Psychoanalysis and Cinema. Bloomington: Indiana University Press.

Williams, Linda. 1991. „Film Bodies: Gender, Genre, and Excess”. Film Quarterly 44/4: 2-13.

Williams, Linda. 2010. Hard core. W ładz̨a, prayjemność $i$,szaleństwo widzialnego. Tłum. Justyna Burzyńska, Irena Hansz, Miłosz Wojtyna. Gdańsk: słowo/obraz terytoria.

Williams, Linda. 1984. „When the Woman Looks”. W Re-vision: Essays in Feminist Film Criticism. Red. Mary Ann Doane, Patricia Mellencamp, Linda Williams. Frederick: University Publications of America. 
Agnieszka Kotwasińska - doktor literaturoznawstwa, kulturoznawczyni i amerykanistka, absolwentka Instytutu Anglistyki i Ośrodka Studiów Amerykańskich na Uniwersytecie Warszawskim. W rozprawie doktorskiej analizowała transformacje struktur rodzinnych we współczesnych horrorach pisarek amerykańskich. Od 2017 asystentka w Ośrodku Studiów Amerykańskich UW, gdzie prowadzi zajęcia z literatury amerykańskiej, literatury gatunkowej, kina grozy i nowych mediów. W badaniach skupia się na procesach tworzenia się kanonów literackich i filmowych, kwestii ucieleśnienia w tzw. gatunkach niskich oraz reprodukcji śmierci w horrorze. Od kilku lat coraz rzadziej stosuje psychoanalityczne teorie kina i literatury, a coraz chętniej sięga do feministycznego nowego materializmu i schizoanalizy.

\section{DANE ADRESOWE:}

Ośrodek Studiów Amerykańskich

Uniwersytet Warszawski

Al. Niepodległości 22

02-653 Warszawa

EMAIL: a.kotwasinska@gmail.com

CYTOWANIE: Agnieszka Kotwasińska. 2017. Intensywna podróż: od psychoanalizy do schizoanalizy kina. Praktyka Teoretyczna 3(25): 371-383.

DOI: $10.14746 /$ prt.2017.3.18

\section{AUTHOR: Agnieszka Kotwasińska}

TITLE: Intensive Voyage: From Cinepsychoanalysis to the Schizoanalysis of Cinema

ABSTRACT: The aim of the article is to trace how the critique of psychoanalysis, developed by Gilles Deleuze and Félix Guattari in Anti-Oedipus, has influenced Anglo-American film theory in the last two decades. In the first part of the article, the author describes a somewhat peculiar theoretical impasse that has plagued film studies; a blockage caused by an overemphasis on psychoanalytic interpretations which revolve around identification, spectatorship, and representation. In the second part, the author presents selected publications that have entered into a creative dialogue with both cinepsychoanalysis and schizoanalysis, and includes two interpretations of famous horror movies: Psycho and The Dawn of the Dead. In both cases psychoanalytic commentary is pushed aside, while the deleuzian-guattarian concept of desire and the notion of an affective film experience are moved into the foreground.

KEYWORDS: Anti-Oedipus, schizoanalysis, cinema, film theory, psychoanalysis, sensation, horror, Psycho, zombie, representation. 